\title{
Design Thinking for Sustainable Development
}

\author{
Mara Zeltina \\ Liepaja University \\ mara.zeltina@liepu.lv
}

Article History: Received: 10 November 2020; Revised 12 January 2021; Accepted: 27 January 2021; Published online: 5 April 2021

\begin{abstract}
The complexity of environmental and sustainability challenges has created an ongoing need for innovative and integrated approaches to address them. Design disciplines have a long history. The method "design thinking", originally applied in architecture, engineering and business, has led to new and creative problem solving, thus creating much potential for use in sustainable development planning. While principles of good design are well established, there has been limited integration of design thinking with environmental science, sustainable development planning and education.

This research was focused on how a sustainability approach can be merged with design thinking to develop socially responsible and environmentally sustainable products and services. The case study has been carried out in the master's study course Sustainable Development Planning. Some of basic principles and stages of design thinking, such as empathy, creativity, collaboration, responsibility and interdisciplinary approach have been tested by using students project work evaluation regarding certain criteria and survey after the study course.

The first results of approbated design thinking principles and methods, significant advantages and disadvantages and the perspective of using this method have been analysed and discussed. As the result from this study proposals for the improvement of the content of this study course and related study courses (a study course on sustainable development issues is compulsory in all undergraduate study programs in Latvia) and for the specification of test tasks have been developed, considering also future needs to provide the study course remotely.
\end{abstract}

\section{Keywords}

sustainability; design thinking; interdisciplinarity; master studies

\section{Introduction}

Design has long been understood as creating aesthetic, visually beautiful and functional products. Although interpretation of the nature and relevance of design has been historically different, the recipient of design is invariably a human. The subject-based environment has always accompanied the development of humanity, and consequently the design must be analysed not only in the context of economic growth, but also in the context of socio-economic, ecological and cultural history.

Design historians believe that just as industrialisation (the first two industrial revolutions) took place, there was a change from society and economy where a human was preparing heritable, long-serving things to a society where things gained short-term value, thereby facilitating their faster turnover of use with a shorter life cycle. The linear economy model (take-make-use-dispose) led to an increase in resource consumption, environmental pollution and social inequality.

H. Simon highlights the beginning of design thinking [16] by stating that design as a creator of better life is at the core of any profession. As designers work with what could exist in the future, compared with artists and scientists, who are working in the present, it is a complex, holistic and interdisciplinary action. Design process is characterized by part of innovations that can take the form of a product, service or systems design, information or infrastructure design, as well as design thinking (DT). Since 1960, DT has been formulated and analysed by both scientists and practitioners. Authors define DT differently and such as other relatively new concepts, DT does not have a single definition.

Design thinking (DT) method has historically been much used in solving complex, changing, disputable issues of the interested parties in an integrated way. Challenges of a similar nature in the society are related to achievement of sustainable development (SD) objectives, therefore DT method has a great potential.

Although DT strategy (analytical, iterative, imaginative), principles and methods are well-developed, it is little integrated into the sustainability science and education for sustainable development (ESD). The existing use of DT action has been superficial. 
Is it possible that based on various theories, methods and practices of DT in the contextual interaction with external systems to define DT as a method, which promotes ESD in Master studies?

In this context the objective of the study is to define the DT as a method for the implementation of ESD in Master studies.

\section{Literature Review}

DT as a choice of set of manners and ways of thinking for ESD implementation is determined by its iterative, dynamic approach, which is strongly justified in necessities of final users and which can be used for any scale of problem-solving.

DT has been described for the first time as an applicable process and method in different fields, including education, by the professor Rowe from Harvard University [12]. As Rowe states, in the DT centre are creative, problem-solving and innovation skills, it is the ability to notice linkages between things we recognize. Over time protagonists and interpreters of DT had been discussing about types, number of stages and methods of DT process.

In the 21 st century, the term DT is used by authors such as founder of the global design company IDEO and a professor of the Stanford Design school David M. Kelley, Tim Brown [2], Lucy Kimbell [7] and others.

Despite that various authors have different interpretations about DT structure (toolkit of steps 3, 4, 5 or 7; figures 1 and 2), the main idea is similar - an ability to listen and investigate problems of the audience, necessities, existing possibilities and its assessment from the users' point of view, so that solutions created would be in demand.

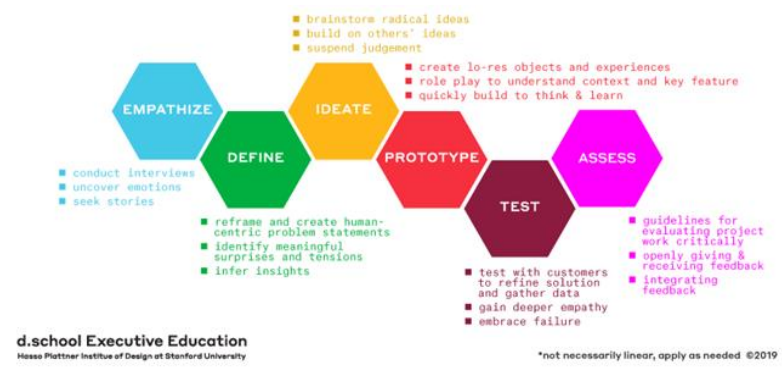

Fig 1. Design Thinking Process Diagram

The research is based on design methods summarized by Vijay Kumar (Fig. 2), which covers the real and abstract part of thinking process.

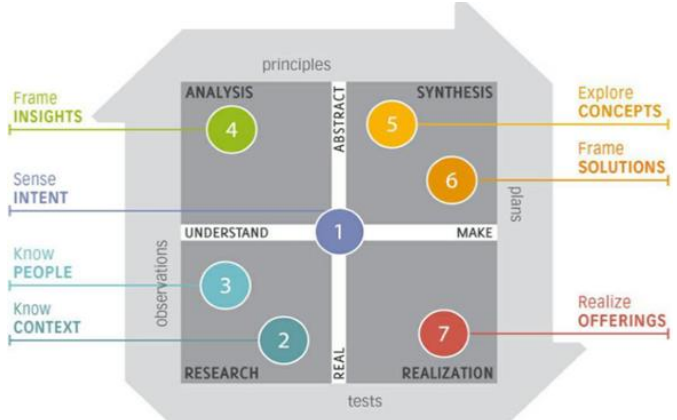

Fig 2. Design Methods Structure [9]

Summary of several interpretations is given in Table 1.

Table 1. Comparison of Several Design Thinking Process Models [12] 


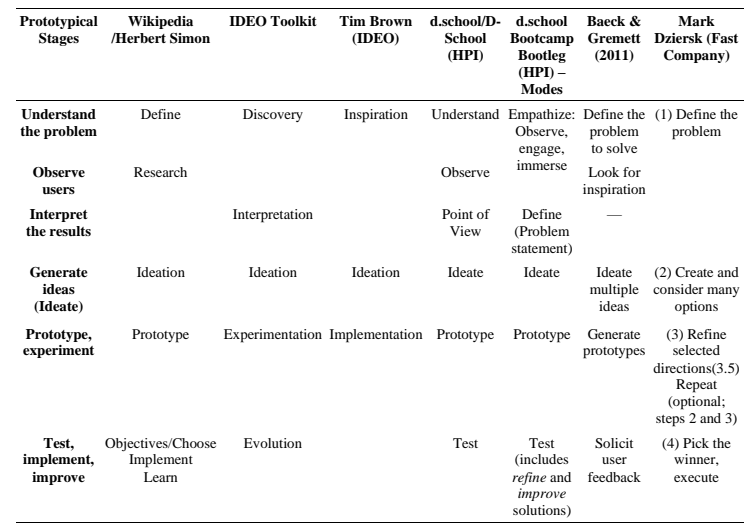

As the main criterion for justifying the choice were stated the most essential characteristics of DT that comply with ESD:

- human-oriented;

- group collaboration in an interdisciplinary team;

- creation of ideas and experimentation;

- prototyping;

- creation of values.

\section{Methods}

The research was carried out as a qualitative, interdisciplinary case study. The approbation of DT methods has been performed in Liepaja University, in the professional Master study programme "Management Science". The interdisciplinarity of the research was ensured by the fact that each of the five work groups consisted of students from all three sub-directions of this programme - business, society and education management. In the research were participating 19 students.

In the research the following methods were used:

1) scientific literature and theories about paradigms of DT and SD, practice methods and use of DT in different fields, descriptive analysis;

2) development of pedagogic task and approbation in the framework of the study course "Sustainable Development Planning";

3) development of the assessment criteria system for the use of DT process.

The research was implemented in 4 stages:

1) defining a task, which includes the problem's identification in relation to Liepaja University and the development for offering solution by using DT approach;

2) monitoring of the process, including the assessment of progress report on defining the problem;

3) presentation of the final result;

4) self-assessment of the development process (made by students).

Based on the structure of DT, the developed system of the process assessment included the following criteria:

1) openness (respect for all opinions in the work group, courage to be wrong);

2) putting yourself in the user's "shoes";

3) expression of abductive reasoning;

4) development of intuitive assumptions, using the critical thinking and feedback;

5) specificity of the precised problem;

6) visual thinking;

7) novelty of the possible solution.

Outside the specific criteria students were also asked a question: "What made the greatest difficulties and obstacles at work?"

\section{Results}

Implementing the first stage of the work development - observation, empathy, understanding and defining the problem - students, mainly based on the results of observations, their feelings (Fig.3). Although the Master students do not stay every day at the university, they did not have difficulties with putting themselves in the user's "shoes". Four out of five work groups also used the survey method to find out opinions of other target 
groups on identified problem. All defined problems comply with SD objectives - a lack of contemporary, energy efficient and creatively non-formal complex of rest rooms for students (choice of two work groups); a lack of a room for childcare and play (choice of one work group); a non-systematicality of information signs in the main building (choice of one work group) and a lack of free drinking water refilling points (choice of one work group).

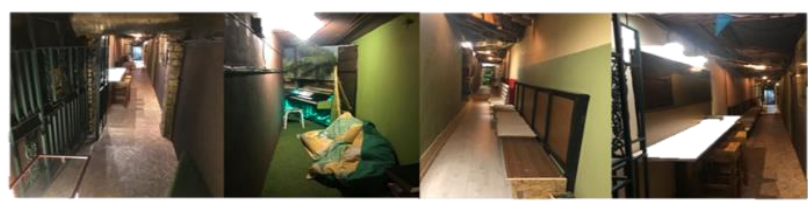

Fig 3. Example of observation (photo-fixation)

The proposed solutions include SD principles, using both the adaptation of ready-made solutions (in four cases) and the finding of original solutions (in one case) for creating prototypes (fig. 4).

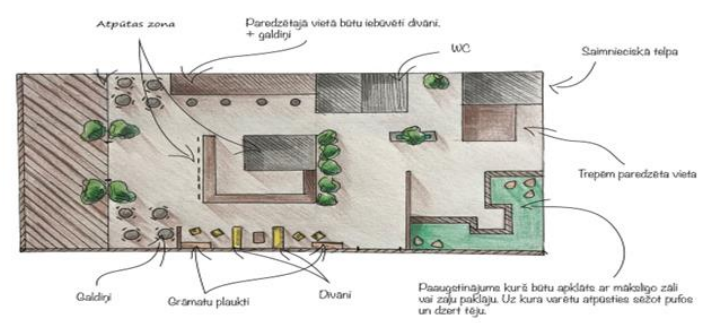

Fig 4. Prototype for complex of rest rooms for students

Due to COVID-19 emergency situation the testing phase of the prototypes had to be replaced by other methods - photo visualization, a survey of potential users.

The self-assessment of work groups on the use of DT process for the development of innovations is displayed in Table 2.

Table 2. Self-assessment of DT process in the view of work groups

\begin{tabular}{cc}
\hline Criterion & $\begin{array}{c}\text { Assessment (10-point system, where "10" the highest } \\
\text { evaluation of the achievement; medium) }\end{array}$ \\
\hline Openness & 9 \\
Putting yourself in the user's "shoes" & 10 \\
Expression of abductive reasoning & 8 \\
Development of intuitive assumptions using the critical & 9 \\
thinking and feedback & 7 \\
Specificity of the updated problem & 9 \\
Visual thinking & 7 \\
Novelty of the possible solution & 9 \\
\hline
\end{tabular}

In the summary of the self-assessment results lower assessments have been given by the work groups to the criteria for the specificity of the problem and the novelty of solution. It shows that analytical design process has mostly been used as opposed to imaginative design process $[5,6]$.

In response to the question about the major difficulties in the use of DT process, the restrictions imposed by the emergency situation have been indicated, which limited possibilities for the prototype testing.

\section{Discussions}

As conditional synonyms of DT are used several ways of thinking, for example, integrative thinking a way of thinking based on finding new alternatives, not the choice from already existing possibilities. In this 
context by the result of design process are understood not only visual solutions, but also the strategy and development planning, implementation of innovative learning methods, establishment of applications' software and internet platforms and other innumerable interdisciplinary activities that become part of user's experience.

Even though there is relatively little research on the importance of integrating design thinking in higher education the methodological focus of the research carried out in certain areas can be compared. Possibilities of using DT principles and methods and approaches in the context of pedagogy in recent years have been investigated in the education of functional design, medicine and social workers by focusing on different aspects of DT - design approaches for sustainable welfare in Master thesis of design students, theoretical models with number of different thinking stages for testing, use of DT approach in the development of study course programs (Curricula) within the education of medicine highlighting a human-centered approach and involving both the students and the academic staff $[3 ; 8,4]$.

Several authors point to the need for further research on the methodology for application DT techniques in different fields $[3,10,12]$.

It is concluded in the European Union that the most essential impact on the environment (in the amount of more than $80 \%$ ) is directly made by the development stage of the product design [17]. In the 21 st century, particularly topical are words sustainability, third industrial revolution, financial and social well-being, which is achieved by the help of innovative growth, as well as expressions of design with a new form, content and usage in the concrete system of political ideology, ecology and epoch social system. The inclusion of sustainability and SD in almost every aspect of life has become the norm for understanding of the modernity and the keyword in the policy planning documents of Europe and national countries [14]. Sustainable Development Strategy of Latvia, which defines strategic objectives, priorities and tasks for sustainable and balanced development of Latvia until 2030 [15].

The objective of ESD education is to help a human form attitudes, skills and knowledge, in order to make reasonable choices for the benefit of himself or the surrounding people in the present and future, as well as to collaborate in accordance with taken decisions. The transition from a linear economy model to a circular economy model, which is one of the preconditions for sustainability. Designers have the decisive role in the development of a new model, moreover this model facilitates ESD and improves the employment [1]. The article deals with the question how to integrate the sustainability approach and the methodology of DT in studies for creating innovations to promote the understanding of prospective professionals about the impact of specific solutions on the life quality of the individual and the community, the environment and the social interaction. Sustainability-oriented innovations are irreplaceable for the provision of sustainable consumption and production and the transition to a circular economy [3].

The methodology of DT, which is based on the concentration towards the user, observation and empathy, integrative thinking and abductive reasoning, visualization and prototyping is widely used in problem-solving in different fields.

\section{Conclusion}

The results of the case study demonstrate that the methods of DT can be successfully integrated in the study process at higher level studies to implement ESD principles. During the development process of problemsolving Master students verified and strengthened skills of interdisciplinary collaboration, observation, understanding of users' necessities, iteratives and visualization. The novelty of solutions and specificity are more problematic.

It could be explained from two aspects:

1) various previous experience of students, professional experience. Regarding differences in opinions of the first and the senior course students, approaches of experts and beginners (novice), also the studies of other authors demonstrate the practical importance of DT principles $[8,11]$;

2) the necessity for each study programme to define a specific competence model of DT (possibly to use separate process elements of DT) and to use it also in other study courses. Students can acquire the DT skills only by practicing, and the highly interactive character of the approach requires adequate preparedness for all academic staff ensuring the achievement of study results and the implementation of the model of competences $[4,11]$.

Innovations is the focus of both the DT and the circular economy, so in further research attention must be paid on the development of students' innovation skills in other study courses and academic system. Developing DT methodology, it is partially possible to adapt also to online study process. 


\section{References (APA $6^{\text {th }}$ edition)}

[1]. Andrews D. (2015). The circular economy, design thinking and education for sustainability. Local Economy. The Journal of the Local Economy Policy Unit, vol.30, issues 3., pp. 305-315, Online available from https://doi.org.10.1177/0269094215578226.

[2]. Brown T., Katz B. (2011). Change by Design. The Journal Innovation Management, New York: Harper Collins Publishers, pp. 381-383, Online available from https://doi.org.10.1111/j.15405885.2011.00806.x.

[3]. Freimane A. (2015). Dizains ilgtspējīgai sociālai labklājībai. Dizaina paradigmas maina. Promocijas darbs. Rīga: Latvijas Mākslas akadēmija, , pp.1-178.

[4]. Gottlieb M., Wagner E., Wagner A., Chan T. (2017). Applying Design Thinking Principles to Curricular Development in Medical Education. AEM Education and Training, pp.21-26, Online available from: https://doi.10.1002/aet2.10003.

[5]. Holt K. (1991). The impact of technology strategy an the engineering design process. Design Studies, vol.12, Issue 2., pp. 90-95. Online available from: https://doi.org/10.1016/0142$\underline{694 X(91) 90050-7}$

[6]. Kelley D., Kelley T. (2013). Creative Confidence: Unleashing the Creative Potential within Us All". New York: Crown Publishing, pp. 1-288.

[7]. Kimbell L. (2011). Rethinking Design Thinking: Part I. Design and Culture". The Journal of the Design Studies Forum, vol. 3, No 3., pp. 285- 306.

[8]. Krūmiņa A.A. (2018). Dizaina domāšana pedagogijas kontekstā. SOCIETY. INTEGRATION. EDUCATION, Proceedings of the International Scientific Conference, Volume IV, May $25^{\text {th }}$ $26^{\text {th }}, \mathrm{pp} .423-434$.

[9]. Kumar V. (2012.) 101 Design Methods: a Structured Approach for Driving Innovation in Your Organization. New Jersy: Wiley, pp. 1- 336.

[10]. Lozano R. (2011). The state of sustainability reporting in universities. International Journal of Sustainability in Higher Education, 12(1), pp. 67-78, Online available from: http://dx.doi.org/10.1108/14676371111098311.

[11] Razzouk R., Shute V.J. (2012). What Is Design Thinking and Why Is It Important? Review of Educational Research, pp. 330-348, Online available from: https://doi.10.3102/0034654312457429.

[12]. Rowe P.G. (1991). Design Thinking. Mit Press, pp.1-227.

[13]. SAP User Experience Community. Introduction to Design Thinking. (2012). Available at: https://experience.sap.com/skillup/introduction-to-design-thinking/ (accessed Apr. 17, 2020)

[14]. Sustainable development goals, (2015). Available at: https://www.un.org/sustainabledevelopment/sustainable-development-goals/ (accessed March $\underline{20,2020)}$

[15]. Sustainable Development Strategy of Latvia until 2030. Available at: https://www.pkc.gov.lv/sites/default/files/inline-files/LIAS_2030_en_1.pdf (accessed March 20, 2020)

[16]. Simon H. A. (1969.) The Sciences of the Artificial. Mit Press: Cambridge, US. Updated third edition from, pp . 1-123.

[17]. Thackara J. (2006). In the Bubble: Design in a Complex World. London: The Mit Press, pp.289293, Available

at: https://www.researchgate.net/deref/http\%3A\%2F\%2Fdx.doi.org\%2F10.7551\%2Fmitpress\%2F37 $\underline{02.001 .0001}$ 